\title{
Correction: Clonal CD8 ${ }^{+} \mathrm{T}$ Cell Persistence and Variable Gene Usage Bias in a Human Transplanted Hand
}

\author{
Joseph Y. Kim, Arumugam Balamurugan, Kodi Azari, Christian Hofmann, \\ Hwee L. Ng, Elaine F. Reed, Suzanne McDiarmid, Otto O. Yang
}

There is an error in the first sentence under the subheading Study Subject, in the Materials and Methods section. The correct sentence is: A 27 year-old woman (HLA A1, B8, B72, DR8, DR17, DQ2, and DQ4) was the recipient of a right hand from a male donor (HLA A2, A11, B35, B51, DR4, DR7, DQ2, and DQ8).

\section{Reference}

1. Kim JY, Balamurugan A, Azari K, Hofmann C, Ng HL, Reed EF, et al. (2015) Clonal CD8 ${ }^{+} \mathrm{T}$ Cell Persistence and Variable Gene Usage Bias in a Human Transplanted Hand. PLoS ONE 10(8): e0136235. doi: 10.1371/journal.pone.0136235 PMID: 26287728

\section{G OPENACCESS}

Citation: Kim JY, Balamurugan A, Azari K, Hofmann C, Ng HL, Reed EF, et al. (2015) Correction: Clonal $\mathrm{CD}^{+} \mathrm{T}$ Cell Persistence and Variable Gene Usage Bias in a Human Transplanted Hand. PLOS ONE 10(12): e0146008. doi:10.1371/journal.pone.0146008

Published: December 23, 2015

Copyright: $\odot 2015 \mathrm{Kim}$ et al. This is an open access article distributed under the terms of the Creative Commons Attribution License, which permits unrestricted use, distribution, and reproduction in any medium, provided the original author and source are credited. 